\title{
Creative Drama Study about Intangible Cultural Heritage: Turkish Wedding Traditions
}

\author{
Elvan Yalçınkaya \\ Department of Primary Education, Faculty of Education, Niğde University, Niğde, Turkey \\ Email: elvanykaya@gmail.com
}

Received 27 October 2014; revised 20 November 2014; accepted 12 December 2014

Copyright (C) 2015 by author and Scientific Research Publishing Inc.

This work is licensed under the Creative Commons Attribution International License (CC BY).

http://creativecommons.org/licenses/by/4.0/

(c) (i) Open Access

\section{Abstract}

Education has an important role in protecting the intangible cultural heritage, which is an important part of cultural identity, and transferring it to the next generations. In the Protecting Intangible Cultural Heritage Agreement that is accepted by United Nations Educational, Scientific and Cultural Organization (UNESCO), it is indicated that it is necessary to arrange educational, sensibility increasing and informative programs that target the general of the society and especially the youth. In line with this target, there are some creative drama practices based on teaching with games about intangible cultural heritage with reference to wedding example. The themes of the creative drama practices have been designed before by the researcher and the drama workshop has been performed by primary school teacher candidates. In the essay, the practice example has been represented in a detailed way; the essay includes the studies of the teacher candidates and their opinions during and after the practices have been indicated in the essay. As a result of the study, it is put forth that the young are interested in wedding traditions. The teacher candidates think that intangible wedding traditions have to be kept alive and creative drama can be used as an effective way in the education of the intangible cultural education. In the frame of the results, it is planned to evaluate the practice results of creative drama activities about the heritage fields told in the Convention for the Safeguarding of the Intangible Cultural Heritage, which are: "oral traditions and expressions, performance arts, other social practices, rituals and feasts, practices and information about nature and universe, handicrafts tradition".

\section{Keywords}

Creative Education, Creative Drama, Heritage, Intangible Cultural Heritage 


\section{Introduction}

Convention for the Safeguarding of the Intangible Cultural Heritage, which was accepted on $17^{\text {th }}$ October 2003 at $32^{\text {nd }}$ General Conference of UNESCO and became valid on $20^{\text {th }}$ April 2006, has come up as a result of a long research and preparation process. It is an international document which aims to protect Intangible Cultural Heritage (Öcal, 2008: p. 5). In this agreement, intangible cultural heritage is defined as the practices, representations, expressions, knowledge, skills-as well as the instruments, objects, artefacts and cultural spaces associated therewith-that communities, groups and, in some cases, individuals recognize as part of their cultural heritage. This intangible cultural heritage, transmitted from generation to generation, is constantly recreated by communities and groups in response to their environment, their interaction with nature and their history, and provides them with a sense of identity and continuity, thus promoting respect for cultural diversity and human creativity. For the purposes of this Convention, consideration will be given solely to such intangible cultural heritage as is compatible with existing international human rights instruments, as well as with the requirements of mutual respect among communities, groups and individuals, and of sustainable development (UNESCO, 2003). "Convention for the Safeguarding of the Intangible Cultural Heritage describes the procedures, methods and opportunities of intangible cultural heritage. This Convention will contribute to protecting intangible cultural heritage, which was inherited from generation to generation, to future generations (Öcal, 2009: p. 8).

According to Ekici (2004: p. 7): “when intangible expression and culture expression are combined intangible culture expression shows up, this expression excludes tangible, physical and technological aspects of culture. The rest: oral (traditional oral creations), aural (traditional musical creations), visual (traditional musical or tuneless games) and practices and credence (traditional credence and related practices). To express these in terms of heritage extent, the heritage should have been produced by a group lived in past and mentioned group should have handed over the heritage to the continuing individual, group or nation.”

"Folklore" thought emerged from modernity and rose as a product of social and cultural transformation. This thought emerged as a new research field at historical beginning of it and in time it should become a wider and more comprehensive study in a period in which variable nature of social studies and interdisciplinary studies become prominent (Kutlu, 2009: p. 15). Academic studies can protect sustainability of intangible cultural heritage nationally and internationally. Recently discussing heritage in terms of interdisciplinary approach has been the main topic. Rethinking Heritage work of Bendix (2009: p. 253), which was published in 2003 at the editorship of Robert Shaman Peckham, pointed out the contributions from geography, history, art history, landscape design and philology. In his work he indicates that either modern philosophers or tourism experts may be interested in cultural heritage. Ulusoy (2011: p. 159) represents the necessity to carry on cultural heritage studies with interdisciplinary approach: "Every nation has to know and protect their own values themselves. Cultural factors such as traditions and customs take an important place. Historians and educationists should introduce basic structure of the society in a better way and should guide new generations by making studies in this field as well as sociologists, anthropologists, literature teachers.” (Ulusoy, 2011: p. 159). The importance of education in inheriting cultural heritage to future generations cannot be denied. Cultural heritage education begins with family. It takes form in school and it continues throughout life.

In the $14^{\text {th }}$ article of Convention for the Safeguarding of the Intangible Cultural Heritage (Education, awareness-raising and capacity-building) following subjects are indicated to be performed (UNESCO, 2003):

Each State Party shall endeavour, by all appropriate means, to:

1) ensure recognition of, respect for, and enhancement of the intangible cultural heritage in society, in particular through:

a) educational, awareness-raising and information programmes, aimed at the general public, in particular young people;

b) specific educational and training programmes within the communities and groups concerned;

c) capacity-building activities for the safeguarding of the intangible cultural heritage, in particular management and scientific research; and

d) non-formal means of transmitting knowledge;

2) keep the public informed of the dangers threatening such heritage, and of the activities carried out in pursuance of this Convention;

3) promote education for the protection of natural spaces and places of memory whose existence is necessary for expressing the intangible cultural heritage. 
According to Kutlu (2009: p. 14) “Agreement says every country should develop its own intangible heritage in education and communication corporations in the first instance and evaluating all of cultural transmitting processes." According to agreement intangible heritage should be thought beginning with primary school. Besides it is emphasized that there should be some extracurricular informative studies about intangible cultural heritage.

In Turkey "Public Culture" lesson has been put into action at $6^{\text {th }}-8^{\text {th }}$ grades in order to develop above mentioned aims in the frame of Safeguarding of the Intangible Cultural Heritage. Besides one of the learning domain out of eight learning domains of Social Studies lesson that is begun to be taught at $4^{\text {th }}$ grade is "Culture and Heritage”. This teaching field is explained in Social Studies Curriculum:

"Students accept the necessity of developing and protecting national conscious forming culture by learning and adopting main elements formed Turkish Culture. Students realize the importance of cultural elements in forming national identity of societies. Thus they realize that cultural elements tell apart from other societies and these elements contribute cultural heritage to be developed nationally and internationally. Primary school $4^{\text {th }}$ and $5^{\text {th }}$ grade students realize that they are affected from their family, their school and the society they live in. Student explores cultural elements forming him/her and the family. He/she learns to arrogate culture to himself/herself via cultural activities. With reference to his/her inner circle he learns historical places, things and structures in Turkey. He accepts that he should know and protect work of art and cultural works. Student takes part in activities aimed at learning other cultures. Students comprehend that culture is formed by people. Student learns the importance of the culture in becoming socialized.” (MEB, 2005: p. 96).

Information about "oral, traditions, visual arts, handicraft custom, social practices, rituals and spread" takes place in the context of social studies lesson. Especially in basic education some activities that will activate student in learning heritage subjects and that is predicated on learning by experience. It is thought that the interest of the student's interest can be caught to cultural heritage subject by creative drama studies. Studies will contribute to their cognitive, affective and behavioral fields of the students about cultural heritage. In fact it can be seen that Turkish culture is close to drama activities. There are applications and rituals based on improvisation and acting. Besides, the term play takes an important role in both Turkish culture and creative drama applications.

Play based creative drama is identified as "animating a word, concept, behavior, sentence, idea, experience or incidence with the help of theatre techniques by developing play and plays” according to San (1990). According to Baldwin and Fleming (2003) drama and acting as a creative way of learning is about six fields directly or indirectly. These fields can be summarized as (Baldwin and Fleming, 2003: p. 9):

Drama is a tool to offer personal, social and emotional development.

Drama is a means contributing the development of communication, language and literacy.

Drama is a tool to understand cognitive enhancement and the world.

It is a vehicle for mathematical development.

It is a means to develop creativity.

"The importance of creativity and its relation between culture and education have become more apparent gradually in the recent century. Educators have accepted the importance of creativity and creative thinking in future progress of a nation and satisfying the educational difficulties caused by labor force once again. Creative drama is at the center of drama process. Students can learn new information using their creativity in different ways, they can develop their abilities and use these abilities and they can gain more insight by drama” (Baldwin and Fleming, 2003).

According to Landy (1982) drama is natural and spontaneous like a game; it is social and ceremonial like a ritual; it is like rehearsing, previewing and reviewing experiments, besides it is like dealing imagination, wishes and dreams. As Baldwin and Fleming (2003: p. 48) represented "ritual is an important tool of life culture and theatre and has also an important role in education. Ritual can be used to identify and emphasize the important moments in drama. Once identified rituals can be used again and again and can provide a reliable reference guide and community feelings”. It is known that rituals are as old as history of humanity. Landy explains historical progress of rituals and drama:

"Historically drama is one of the oldest activities. When the community gathered together drama used to be 
performed for ceremonial purposes such as good hunt, plentiful precipitation or long life to the new leader. Drama has been a natural way of learning in the development of history of humanity. The importance of drama has been accepted since humanity existed. All primitive communities in the world have used dramatic dances to rehabilitate sanity” (Landy, 1982).

Kara (2010: p. 1181) expressed in his work that there are documents about how far drama do back in Turkish Culture and in the essay published at 1934 in Politics Gazette of Belgrade of M. M. Nikolic the researcher he pronounced that Turks know drama for more than four hundred years. The existence of rituals and social applications those tried to be kept alive offers important clues about how drama is important in Turkish culture and its history. Yavuzer, Dikici and Gündoğdu (2008) presented the close relationship between Turkish culture and drama practices with observing that teacher candidates participates creative drama activities eagerly. They said that the most important reason for this is that Turkish public isn't stranger to drama activities because of traditional children's game, rituals held in Anatolia and traditional ceremonies. For instance, while women applying henna to the brie at henna nights, a woman pretending to be drunkard man and entertains them by annoying them. Also, there had been no difficulty in the activities in which girls and boys had to be close and touch each other. Because they had the culture in which people dance the halay by holding hands.

\section{Application Sample (Wedding Traditions)}

Intangible cultural heritage (wedding traditions) themed study has been carried on with Niğde University Faculty of Education Primary School Teaching Department Drama lesson students. At the end of the study the participants have been asked to share their attitudes with the group. Besides, the activities have been photographed with the permissions of the participants.

Drama lesson is compulsory in Faculty of Education Primary School Teaching Department. This lesson aims students to use creative drama as a method in the education of various subjects. The basic aim of creative application is to create awareness in the primary school teacher candidates who will serve about intangible cultural heritage and make them realize that they can make use of creative drama activities.

Application at creative drama consists of three phases those are preparation, animating and evaluation (Adıgüzel, 2006; Üstündağ, 2004).

\subsection{Preparation (Warming up)}

Participants asked to walk around freely according to the rhythm of the regional music. The participants are said to say "hello, welcome" and shake hands to the closest friends when the music stopped. At the end of this activity, which was done for the communication, the participants asked to "imagine themselves dancing in a wedding, acting in appropriate according to this role and stop moving when the music ended". The participants dance with different dance music belonging to various regions of the country. When the music stops the participants freeze (Figure 1). They continue dancing with the music.

The participants are asked to go into a huddle. Different colored handkerchiefs are given to everybody's hand. They are asked to drop the handkerchief when the leader says grab and grab the handkerchief fast when the leader says drop. It is announced that the ones puzzled and lagged will be eliminated and the winners will be applauded at the end of the activity (Figure 2). At the end of the activity every detail about their feelings are asked to the students. In accordance with the answers the leader announces that such games are played for fun in Turkish culture. The participants are asked about similar applications or games in Turkish culture. Direct quotation of a student is that:

Aykut: Sometimes 15 - 20 people come together in houses. One of them performs imitation spontaneously for fun. A man in woman dress comes in and performs imitations. Apart from that; some funny incidents are animated. The aim is to provide cultural coalescence.

Then the leader asks the participants what kind of traditional plays take part in Turkish weddings for fun. The answers of the students are camel game, head game etc. as a result of the answers of the students it is emphasized that "Turkish culture is too rich and some games are called differently in different regions". For example, one of the participant named Seda defines head game like this: "head game is played among men in my hometown. There is a leader in this game. Everyone does what the leader does. The leader punishes the ones who can't do the movements with his belt. Sometimes the leader does hard actions and the players are ridiculed". 


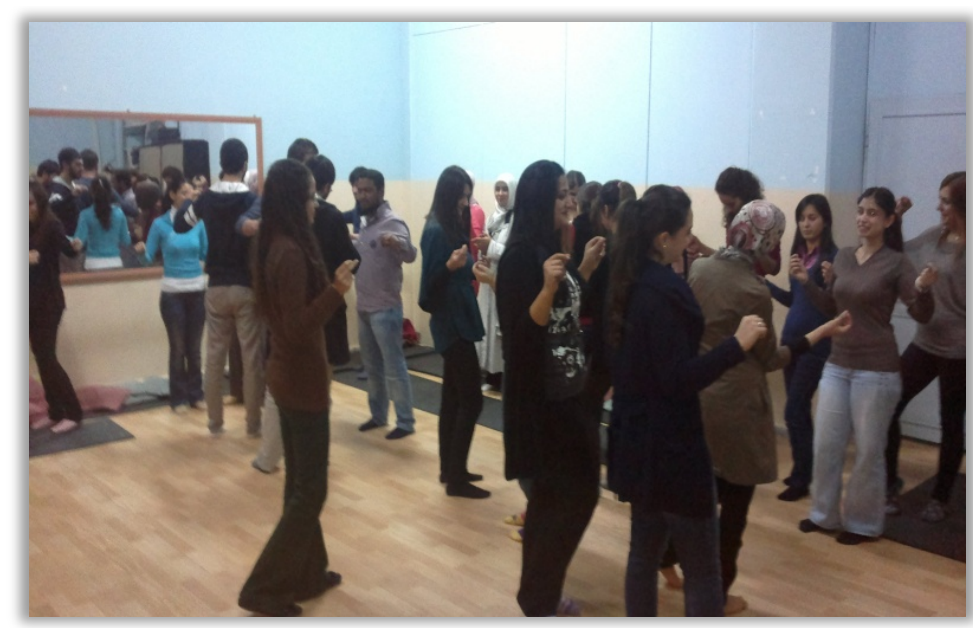

Figure 1. An image from warming up activities.

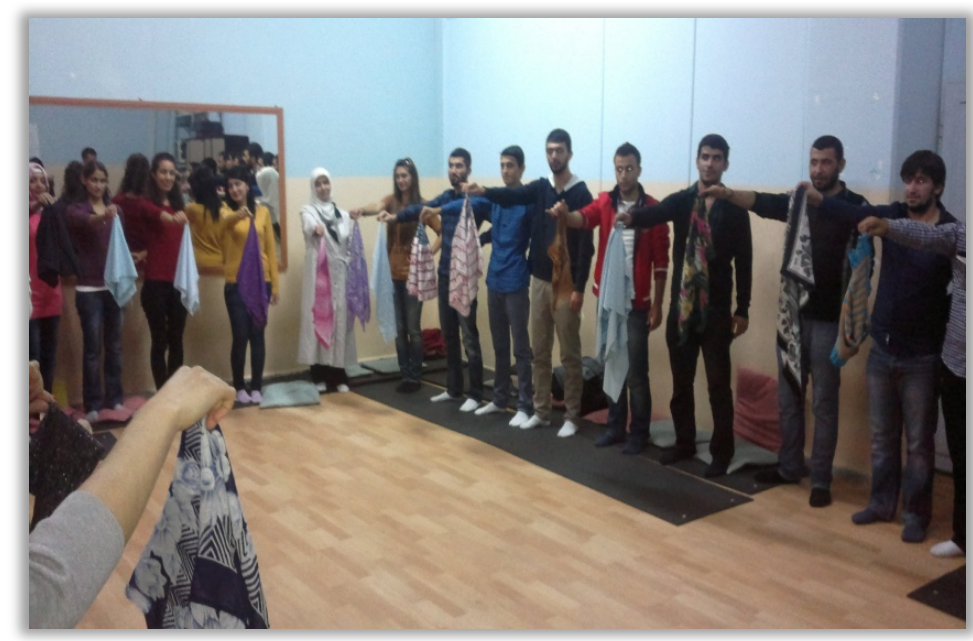

Figure 2. An image from grab-drop the handkerchief game.

Basak says "I am from Kayseri. In our weddings the same game is being played with shawm and drum"; Mert says "The same game is played in Yozgat" and the participant named Cansu says "I am from Ardahan, the same game is being played in my town. But I don't know its name". The leader says the participants that the same game is going to be played in the class. A leader is determined. The participants are asked to hold hands beginning with the leader. They are told to do the exactly the same thing with the leader or else they would be eliminated. The game has been played accompanied by music. The leader began with simple movements, continued with hard ones and at the end of the game the winners have been applauded. In the assessment done at the end of the game, the students emphasized that Turkish culture is very rich. Some students expressed that they come across this game for the first time and they had so much fun.

The participants asked which communal applications are kept alive in their regions. Some direct quotations from the answers of the students are:

Asli: When the bride is taken to the home something such as wheat, sugar, grapes and money are spilled over her. I have heard that this application is to bring plentifulness to the newly founded family.

Mesut: Oil and honey are being rubbed onto the door before the bride enters.

Derya: In my hometown a pot is being broken when the bride comes to home. I have heard that it is believed that the bride will be strong and skilled if she breaks the pot.

Kagan: In my home town a flag is displayed on a tall pole and an onion has been put at the top of the pole. Chicken feathers have been put on the onion. This pole is sticked in front of the wedding house. 


\subsection{Animation}

The participants split up to five groups. Every group member is asked to tell an intangible communal application of their own hometown to the other members of the group. The leader informs the groups generally about the intangible cultural heritage. The entire groups sit in a circle and listen to their group mates sharing. Every group is asked to choose one of these intangible cultural heritage applications and make a picture representing the situation. They are told that they have three minutes to make a picture and they ought to stay still while the application is being displayed. After the preparations of the groups have finished, the pictures have been made and they have been photographed. The first group showed putting gold in hands of bride and groom (Figure 3), the second group showed giving a baby to the bride's lap (Figure 4), the third group showed wheeling presents around the bride's head (Figure 5), the forth group showed the brothers belting the bride (Figure 6) and the fifth group showed pricking the groom (Figure 7) in a still way.

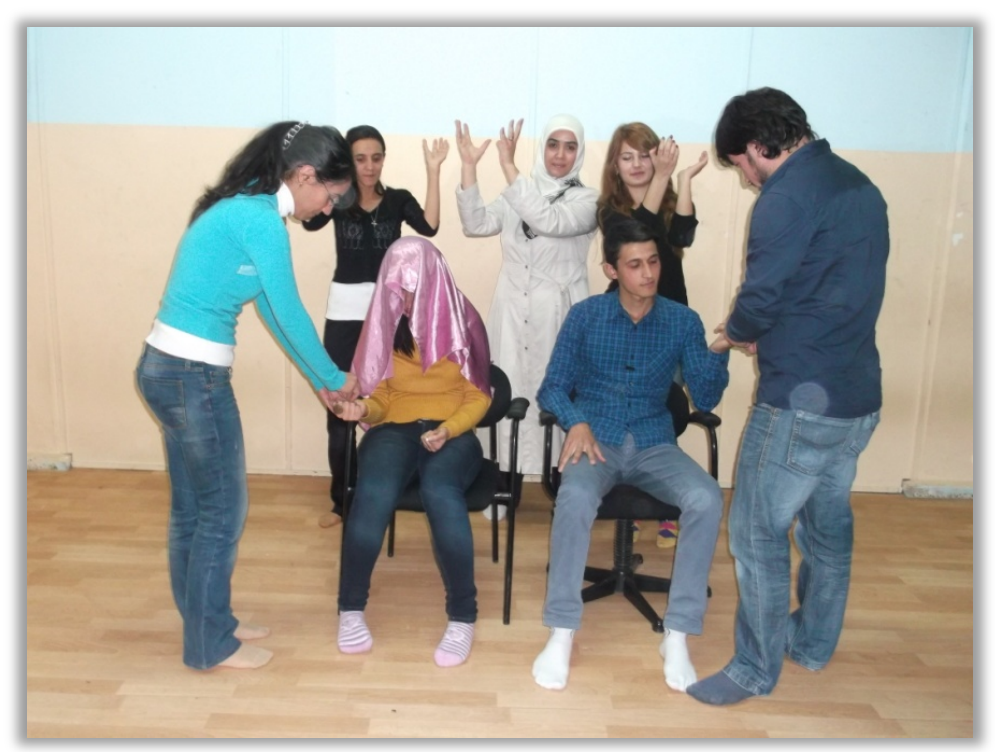

Figure 3. An image of improvisation of putting gold in hands of the bride and the groom.

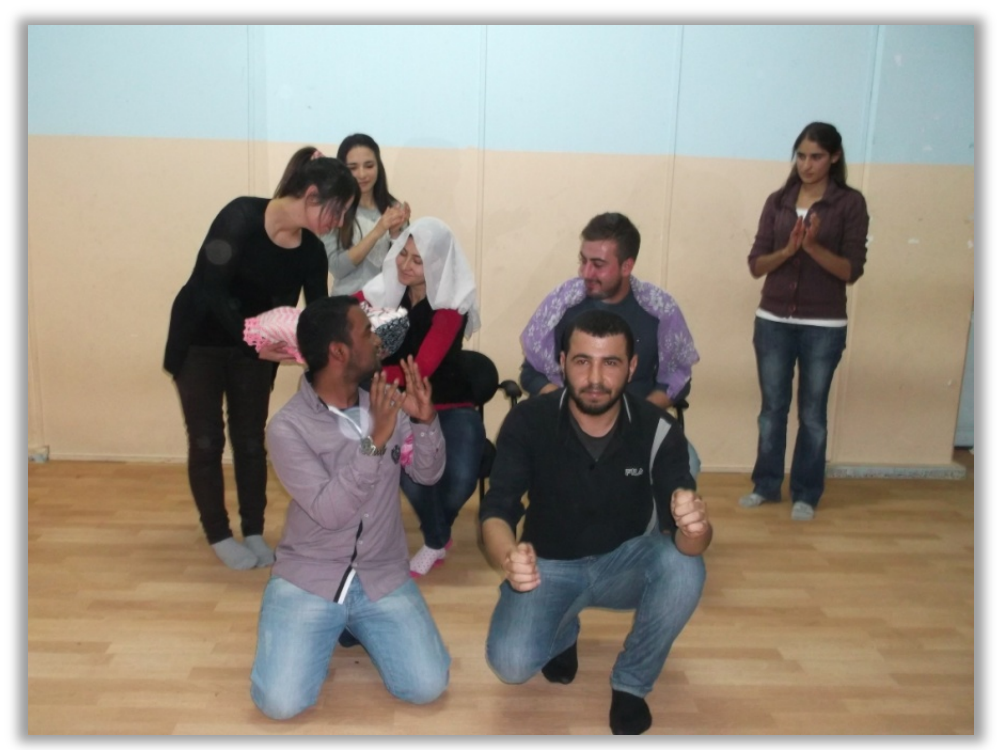

Figure 4. An image of putting a baby to the bride's lap improvisation. 


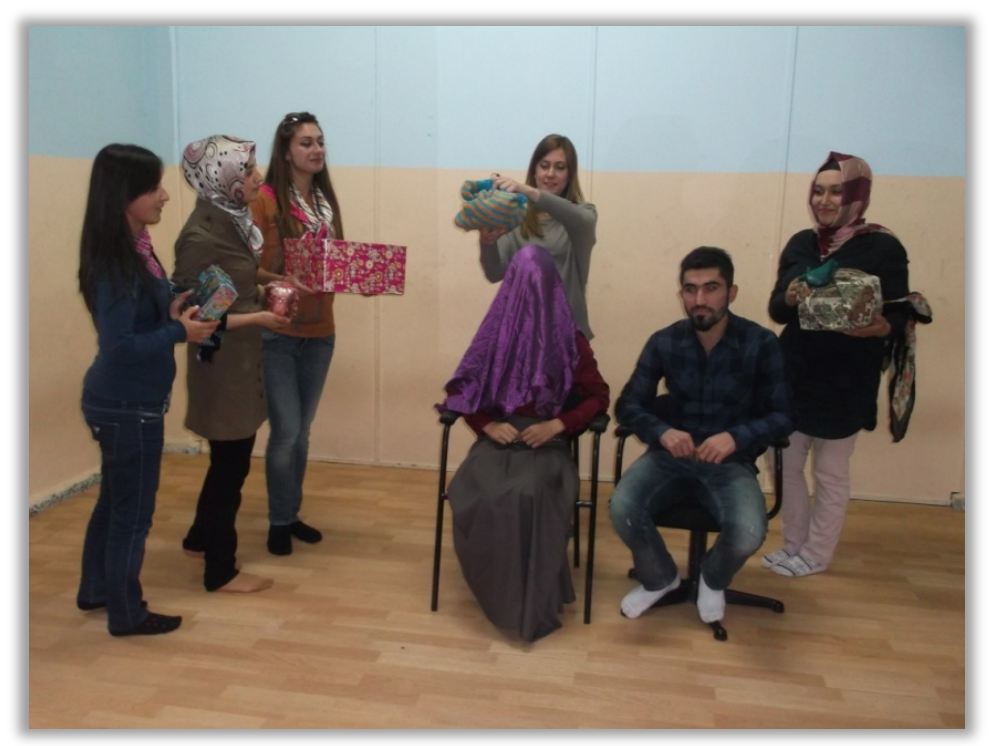

Figure 5. An image of wheeling presents around the bride’s head improvisation.

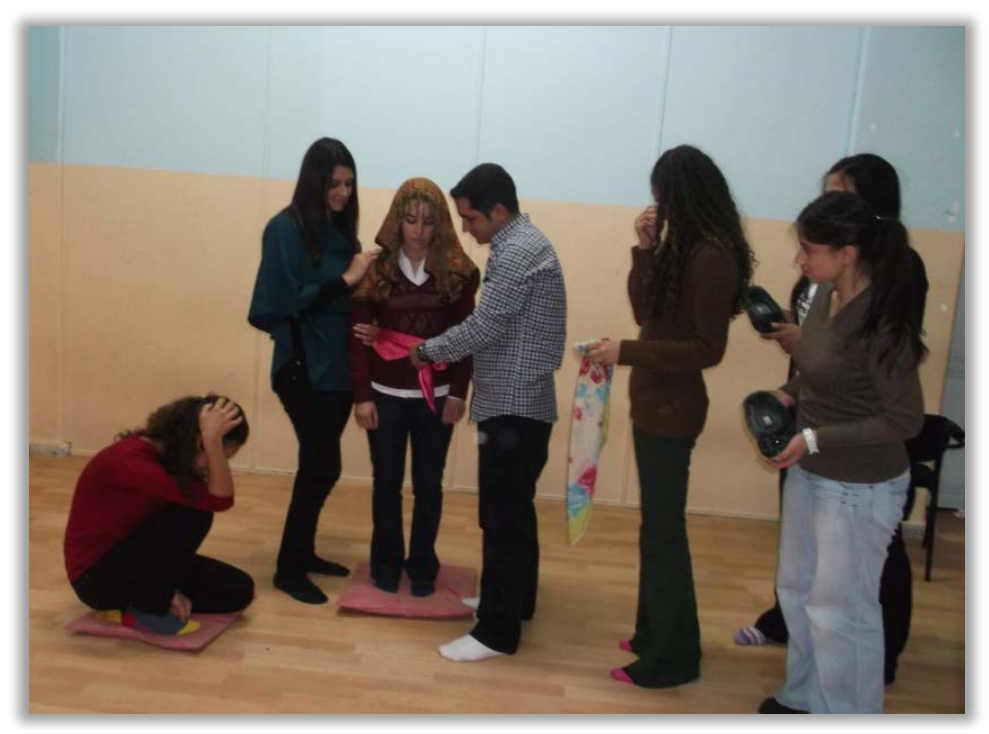

Figure 6. An image of the brothers belting the bride improvisation.

After the photographs of all of the groups have been displayed, the participants are told to draw the people on the photographs out and show what they do by acting. After the animations the participants are asked to share their feelings and ideas with the group.

Yasemin: As a result of the animations I think that we have a very rich culture and these applications should be kept alive.

Onur: I think these applications will be forgotten one day if they aren't kept alive. As teacher candidates we may contribute keeping our intangible cultural heritage by conducting these kinds of activities in the lessons.

Funda: I realized that our cultural heritage is rich during the applications by having fun. I think that these applications aren't kept alive anymore.

\subsection{Assessment}

The participants are asked to share their feelings and ideas about the activities held in this studio. 


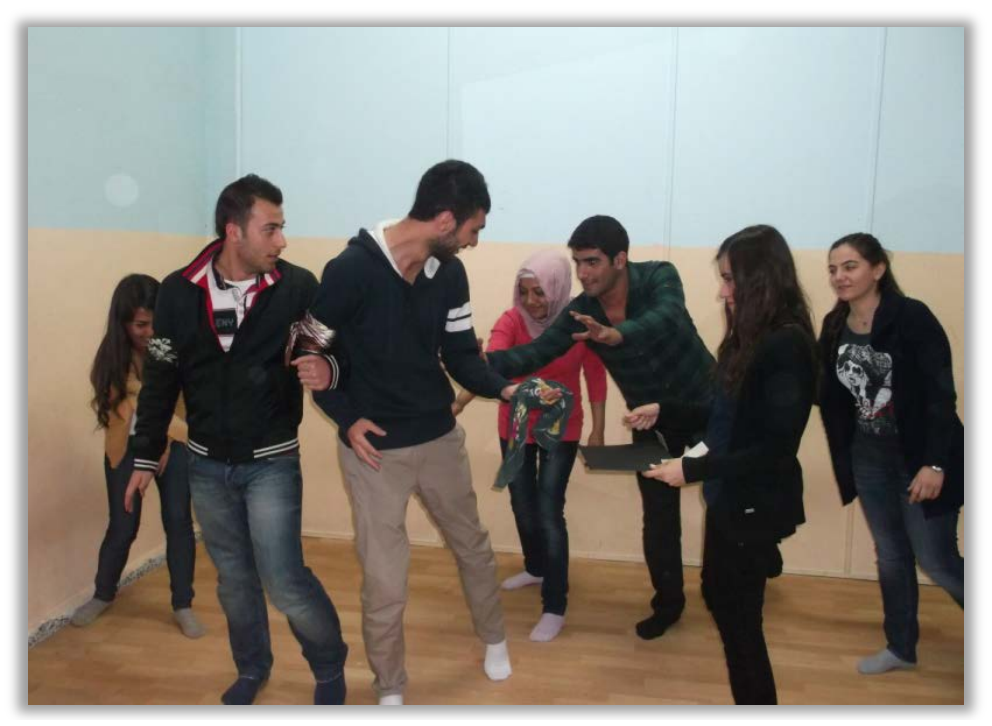

Figure 7. An image of pricking the groom improvisation.

Hasan: I figured out the difficulty of holding a wedding. We saw that the known applications are applied in different ways. There are some applications like betroth, engagement and henna. But these applications differ from region to region.

Meltem: Our weddings are the most important applications of our intangible cultural heritage and they are still been carried on. These traditions are being kept alive by being inherited from generation to generation. We saw that we are keen on wedding ceremonies. We learnt our wedding traditions by having fun.

Asya: I think we couldn't represent our traditions exactly. The bride is made to sit on a chest before exiting her home, someone sit in front of the bridal car and a baby is given to the lap of the bride. These are combined to each other, the reason why we couldn't represent all of them exactly is the fact that our culture is too rich.

Meltem: We tried to animate many traditions in a limited time.

Fatma: As the aim of the study we revived our culture in an amusing way. We tried to animate some of our customs and traditions.

Mehtap: The groups were formed randomly. The members of the groups were from different regions. The traditions of Aegean, Central Anatolia and Eastern Anatolia are different; we tried to perform a common picture by combining them.

Mehmet: Our culture is very rich. There are amusing traditions from west to east of our country. I think that we could animate them exactly.

Ali: We tried to animate different applications about our culture in our way. I realized that different intangible heritage applications are kept alive or aren't kept alive in our region. It formed a sense of belonging.

Cansu: I am from Antalya. We don't have any of these customs in my region, they are too much obvious. I used to see these customs in documentaries.

Esra: We should realize that how our customs and traditions are connective. Because even distant friends want to share each other's happiness when there is a wedding or want to stand by each other in funerals. I realized that customs and traditions are very connective with the help of the improvisations we made.

Sedat: As a teacher candidate I thought that these applications may show what culture is perceptibly in the $4^{\text {th }}$ grade Social Studies lesson.

Hasan: Primary school students must be living these incidents always; they must be seeing these traditions in the weddings of their relatives. But it is possible that they might not be able to understand them literally. They will understand the importance of intangible cultural heritage when they animate in groups under the teacher's guidance.

\section{Conclusion and Suggestions}

In this study, the creative drama activity about wedding ceremonies which are among the most important part of 
Turkish intangible cultural heritage and the opinions of teacher candidates about the applications have been evaluated. The results are given below:

Teacher candidates' attitudes towards creative drama activities about intangible cultural heritage are positive.

It can be said that the teacher candidates are notably interested in wedding traditions.

Teacher candidates think that intangible wedding traditions should be kept alive.

Teacher candidates think that creative drama can be used effectively in teaching intangible cultural heritage.

It is seen that awareness has been formed as a result of the studies about "protecting and respecting cultural heritage" aim of Convention for the Safeguarding of the Intangible Cultural Heritage.

Recently we feel the devastating effect of the globalization on cultures more intensely. It is really important to protect and adopt cultural values and create awareness and sensibility for this subject in terms of national existence (Kolaç, 2009: p. 22). Artun (2004: p. 147) expresses that protecting cultural heritage is not an international issue anymore. Besides, some policies should be developed aimed to determine, protect, promote and transmit intangible cultural heritage by focusing on information and education. He also expresses that intangible cultural heritage is the mirror of the cultural diversity. By using wedding example, it has been tried to create awareness about the importance of intangible heritage, in protecting them and in making effective and authentic activities about intangible cultural heritage.

These suggestions can be made as a result of the study:

More educative studies are necessary to protect Turkish intangible wedding traditions.

Individuals can be made to protect and respect intangible cultural heritage by extracurricular and in curricular creative drama studies about intangible cultural heritage.

Within the context of this study, creative drama teaching plan has been prepared and applied just about Turkish wedding traditions. In the further studies, creative drama activities about "oral traditions and narrations, performance arts, other communal applications, rituals and feasts, information and applications about nature and universe, handicraft traditions" fields, which are indicated in Convention for the Safeguarding of the Intangible Cultural Heritage, can be designed and the application results can be assessed.

This teaching plan can be applied by being rearranged according to the acquisitions taking place in Public Culture lesson teaching plan or primary school $4^{\text {th }}$ grade Social Studies lesson “Culture and Heritage” learning field. The conclusions can be assessed.

\section{References}

Adıgüzel, Ö. (2006). The Concept of Creative Drama, Components and Stages. Yaratıcı Drama, 1, 17-31.

Artun, E. (2004). Exhibition in the Museum of Village of Theatrical Cultural Heritage. Exhibition in the Museum of Intangible Cultural Heritage Symposium Booklet, 147-151.

Baldwin, P., \& Fleming, K. (2003). Teaching Literacy through Drama Creative Approaches. Londra: Routledge Falmer.

Bendix, R. (2009). Heritage between Economy and Politics: An Assessment from the Perspective of Cultural Anthropology. In L. Smith, \& N. Akagawa (Eds.), Intangible Heritage (pp. 253-269). Londra: Routledge Falmer,.

Ekici, M. (2004). Afterwards of a Symposium: Exhibiting the Intangible Cultural Heritage in a Museum. Milli Folklor, 61, 513.

UNESCO (2003). Convention for the Safeguarding of the Intangible Cultural Heritage. www.unesco.org/culture/ich/doc/src/00009-TR-PDF.pdf

Kara, Ö. T. (2010). The First Practitioners of Drama: Turkish Shamans. Turkish Studies, 5, 1180-1191. http://www.turkishstudies.net/

Kolaç, E. (2009). The Importance of Turkish Language Education in Protecting and Raising Awareness on Intangible Cultural Heritage. Milli Folklor, 82, 19-31.

Kutlu, M. (2009). The First Step at the Education of the Safeguarding of the Intangible Cultural Heritage: Folk Culture Course. Milli Folklor, 82, 13-18.

Landy, R. J. (1982). Handbook of Educational Drama and Theatre. Londra: Greenwood Press.

MEB (2005). 6th and 7th Grade Turkish Social Studies Curriculum. http://ttkb.meb.gov.tr/program2.aspx/program2.aspx?islem=1\&kno=39

Öcal, O. (2008). UNESCO and Masterpieces of the Verbal and Intangible Heritage of Humanity. Milli Folklor, 78, 5-11.

Öcal, O. (2009). Intangible Cultural Heritage and the Diversity of Cultural Expression. Milli Folklor, 82, 6-12.

San, İ. (1990). Creative Drama in Education. Ankara Üniversitesi Eğitim Bilimleri Fakültesi Dergisi, 23. 
http://dergiler.ankara.edu.tr/dergiler/40/508/6181.pdf

Ulusoy, K. (2011). Coffee and Coffeehouse Culture in Turkish Society: A Verbal Culture and Social Environmental Education Study. Milli Folklor, 89, 159-169.

Üstündağ, T. (2004). My Creative Drama Teacher’s Diary. Ankara: Pegem A.

Yavuzer, Y., Dikici, A., \& Gündoğdu, R. (2008). A Creative Drama Study in Turkey about Mevlana Philosophy. Research in Drama Education: The Journal of Applied Theatre and Performance, 13, 87-94.

http://dx.doi.org/10.1080/13569780701825419 
Scientific Research Publishing (SCIRP) is one of the largest Open Access journal publishers. It is currently publishing more than 200 open access, online, peer-reviewed journals covering a wide range of academic disciplines. SCIRP serves the worldwide academic communities and contributes to the progress and application of science with its publication.

Other selected journals from SCIRP are listed as below. Submit your manuscript to us via either submit@scirp.org or Online Submission Portal.
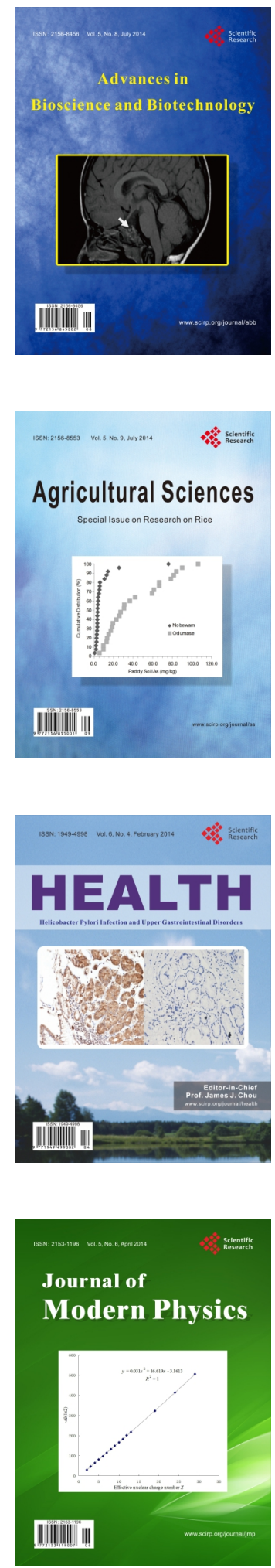
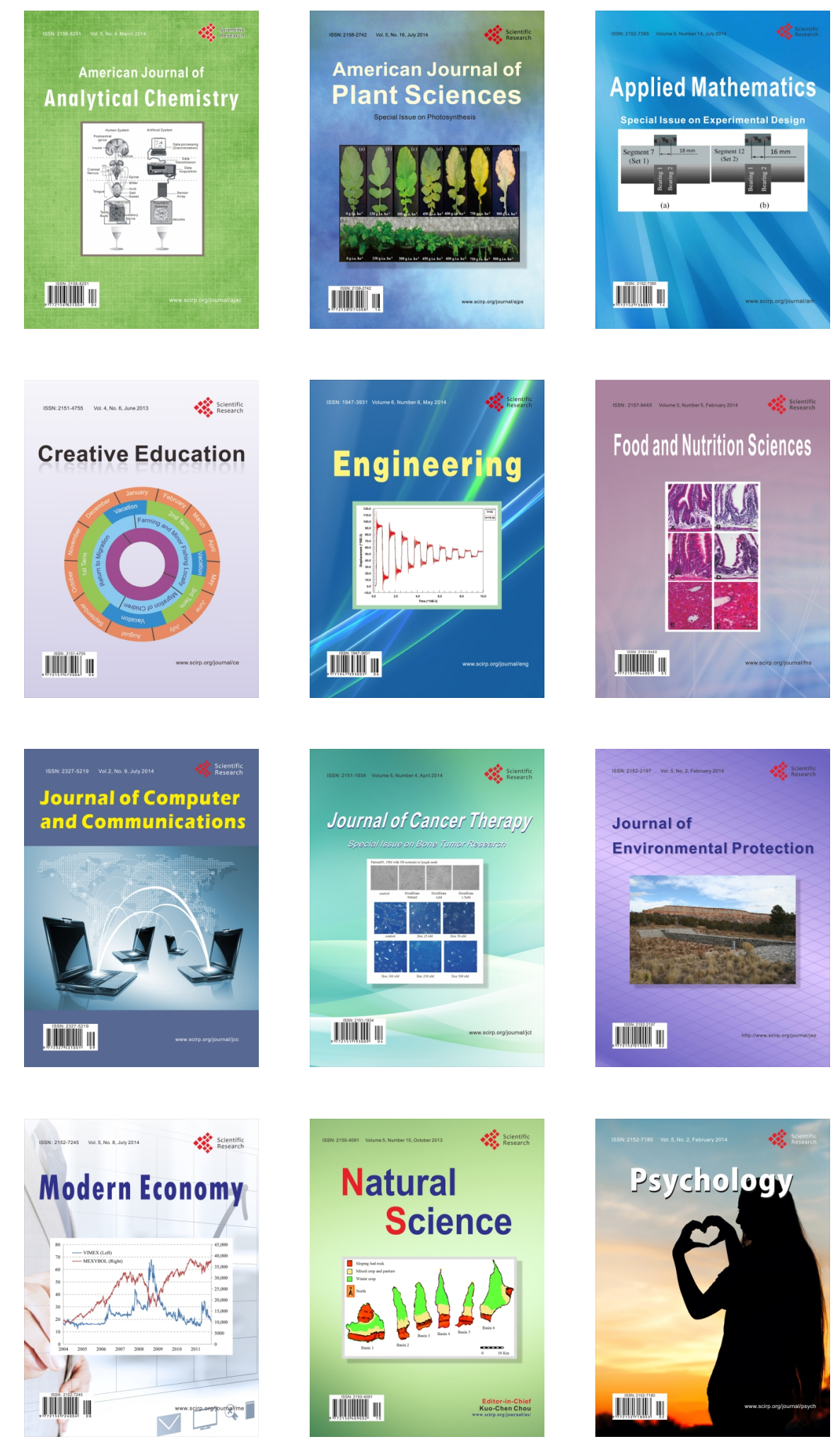